\title{
Anti-diabetic actions of Berry polyphenols - Review on proposed mechanisms of action
}

\author{
Indika Edirisinghe* and Britt Burton-Freeman \\ Center for Nutrition Research, Institute for Food Safety and Health, Illinois Institute of Technology, Bedford \\ Park, IL, USA
}

Received 5 February 2016; accepted 24 April 2016

\begin{abstract}
The incidence of type 2 diabetes mellitus (T2DM) has reached near-epidemic proportions in the Western world with other parts of the world following close behind. Glycemic control is paramount in type 1 diabetes mellitus (T1DM) and T2DM. Berries may beneficially influence glycemic control through the action of their polyphenolic components. While clinical studies on the anti-diabetic effects of berry polyphenols are limited, epidemiological data have indicated favorable effects of berry/anthocyanins intake on development and/or management of T2DM. Furthermore, data derived from in vivo animal studies and in vitro cell culture models are promising. Various molecular targets and modulation of cell signaling pathways in pancreatic $\beta$-cells, hepatocytes, adipocytes, and skeletal muscle cells are among the proposed mechanisms for berry polyphenols and their metabolites' action. Berry polyphenols may exert anti-diabetic effects by (i) enhancing insulin production and reducing apoptosis and promoting proliferation of pancreatic $\beta$-cells, (ii) regulating glucose metabolism by interfering with absorption or by increasing peripheral tissue glucose uptake through insulin receptor-dependent or independent mechanisms via modification of oxidative stress, inflammation or perceived energy status of cell. This mini review discusses recent findings from our laboratory and other studies on the anti-diabetic effects of berry polyphenolic compounds with special emphasis on the cellular and molecular mechanisms involved in the beneficial effects of berry polyphenol compounds.
\end{abstract}

Keywords: Anthocyanins, insulin, glucose, berry fruits, glycemic control

\section{Introduction}

Increased incidence of type 2 diabetes mellitus (T2DM) presents a significant health burden in the United States of America (USA) and other parts of the world. Recent data indicates that in USA, $\sim 9.1 \%$ of the age -adjusted population had diabetes in 2014 and an additional 86 million adults had prediabetes [1]. According to the World Health Organization (WHO) report, the prevalence of diabetes among adults over 18 years of age was $8.5 \%$ in 2014 [2]. Current projections by the Center for Disease Control and Prevention (CDC) predict that over half of the U.S. population will have diabetes or prediabetes by 2020 [3]. The etiology of T2DM is complex in that it results from defects in insulin secretion from the pancreas, impaired action on peripheral insulin sensitizing cells, or a combination of both [4].

\footnotetext{
*Corresponding author: Indika Edirisinghe, PhD, Institute for Food Safety and Health, Illinois Institute of Technology, 6502 South Archer Road, Bedford Park, IL-60501, USA. Tel.: +1 708308 0178; E-mail: iedirisi@iit.edu.
} 
There are two major classifications of diabetes mellitus. Type 1 diabetes mellitus (T1DM) is associated with complete or near-total insulin deficiency of pancreatic $\beta$-cells. T2DM is associated with variable degrees of insulin resistance, impaired insulin secretion with or without moderate to severe $\beta$-cell apoptosis in the pancreas, and increased hepatic glucose production. People with either forms of diabetes mellitus have an increased risk of developing a number of serious chronic diseases affecting the heart and blood vessels, eyes, kidneys and nerves. Importantly, effects on the heart and blood vessels may cause fatal complications such as coronary artery disease and stroke. Cardiovascular disease is the number one cause of death in people with diabetes mellitus [5].

Over the past few decades, lifestyles changes characterized by increased energy intake and decreased physical activity have promoted overweight and obesity resulting in increased incidences of diabetes [6]. Diet/dietary factors also play an important role in preventing diabetes, managing existing diabetes, and preventing, or at least slowing down the rate of development of diabetes complications, highlighting the role of dietary composition. Increased intake of vegetables and fruits is at the center of dietary recommendations for preventing and managing diabetes [7]. In addition to essential nutrient content, fiber and low energy density, vegetables and fruits also contain a wide variety of non-(essential) nutrient compounds such as polyphenolic compounds. Polyphenolic compounds are widely distributed in plant foods, particularly fruits and vegetables, including berries, which are rich sources of the anthocyanin polyphenols [8]. Increasing evidence suggests a positive relationship between consumption of berries and dietary anthocyanins and reducing T2DM risk [9]. A recent study published by Wedick et al. [10] combining 3 prospective cohort studies that included nearly 200,000 US men and women indicated that a higher consumption of polyphenols, particularly anthocyanins derived from blueberries, apples, and pears, was consistently associated with a lower risk of diabetes. Similarly, another analysis of three, large, prospective, cohort studies from the USA that included 200,994 health professionals revealed that consumption of foods rich in anthocyanins, particularly strawberries, blueberries and grapes/raisins, was inversely associated with the risk of T2DM [11]. In line with these findings, a study published by Mursu et al. [12] showed higher intakes of berries correlated with a significantly reduced (35\% lower) risk of T2DM in middle-aged and older Finnish men and no associations were observed with other fruits and vegetables. Taking from this background and epidemiological evidence for a role of berries and anthocyanins as "anti-diabetic" foods/compounds, we review briefly recent findings from our laboratory and other research groups on the anti-diabetic effects of berry polyphenolic compounds with special emphasis on the cellular and molecular mechanisms.

Studies related to the anti-diabetic effects of berry polyphenols were identified in Medline with PubMed searches on the following keywords: "berries" (including names of specific berries, such as "blueberry", "strawberry", "cranberry"), "polyphenols", "anthocyanins", and "flavonoids", in association with "diabetic", "insulin resistance", insulin sensitivity", "glucose metabolism”, glycemic control”, "humans", "clinical trial”, "animal models", "cell culture", "in vitro studies", "In vivo studies", "epidemiological studies". On the basis of search criteria, only studies that used most commonly consumed berries and/or berry extracts that have been associated with mechanisms of action were considered. Studies on individual polyphenolic compounds that the source of the compounds derived were not given or not from berry fruits were excluded.

\section{Polyphenolic compounds in Berry fruits}

Botanically, berries are known as fleshy fruit produced from a single ovary. However, consumers know them as small edible fruits that are brightly colored of red-blue-purple and do not have a pit, although they may contain seeds [13]. Despite the contrasting definitions, berry fruits are a rich source of polyphenols. Polyphenols are a diverse family of compounds which differ in structure and potential bioactivity. Total polyphenol content can vary largely between different berry species, cultivars and under different growing conditions [14, 15]. Total polyphenol contents of 100-300 mg/100 g are common for black currant, raspberry and strawberry and the levels of components can be heavily influenced by post-harvest treatments and processing requiring verification of content in manufactured food products [16]. 
Among the most notable polyphenols in berries are the anthocyanins. The red-to-blue-purple coloration of berries is due to the presence of anthocyanins. Berries contain appreciable amounts of anthocyanins making them the richest dietary source of anthocyanins. Anthocyanins are a type of flavonoid that consist of 2 aromatic rings (A and $\mathrm{B}$ rings) linked by a 3-carbon chain that forms an oxygenated heterocyclic ring ( $\mathrm{C}$ ring). The most commonly identified anthocyandin in berry fruits are cyanidin, delphinidin, malvidin, pelargonidin, peonidin, and petunidin. Anthocyanin content of berries can vary greatly between species and varieties, degree of ripening and growing conditions $[14,15]$. The red-orange color of strawberries is due to the presence of pelargonidin-type anthocyanins in the flesh and skin whereas the deep purple-black colour of black currants is due to the accumulation of high amounts of delphinidin and cyanidin-type anthocyanins in the skin. In addition to anthocyanins, berries contain several other polyphenolic compounds that may contribute to their bioactivity, such as flavonols, phenolic acids, proanthocyanidins, and ellagitannins [17]. The compositions of polyphenols in berry fruits not only define the color and palatability but also influence their possible health benefits.

\section{Potential mechanism of action of Berry polyphenols on anti-diabetic effects}

Recent research from in vitro and in vivo studies supports the anti-diabetic effects of berry polyphenols. "Antidiabetic" effects are generally associated with achieving and maintain glucose homeostasis. Insulin is a central player in glucose homeostasis; however, other non-insulin-dependent mechanisms also play a role in regulating glucose homeostasis. Berry polyphenols have been studied for their effects on insulin dependent/associated mechanisms, such as pancreatic $\beta$-cell function and insulin secretion and peripheral tissue sensitivity as well as insulin independent mechanisms, such as impairment of glucose absorption (Fig. 1).

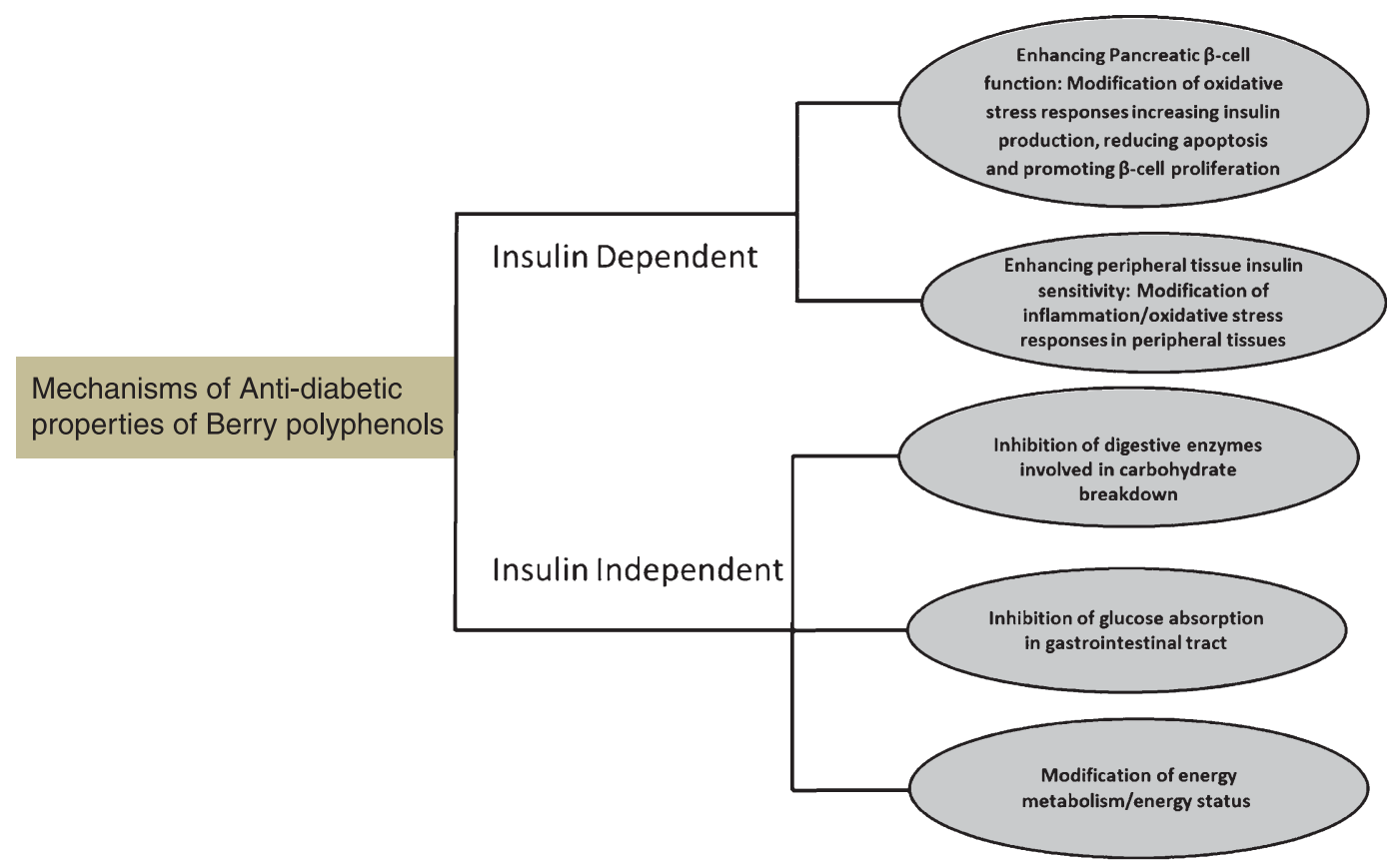

Fig. 1. Berry polyphenols exert anti-diabetic effects by several interrelated mechanisms through insulin dependent and insulin independent mechanism. 


\subsection{Insulin-dependent mechanisms}

\subsubsection{Overview}

When a meal containing carbohydrate is consumed, digested, and absorbed, the pancreas senses the increase in blood glucose concentrations and releases insulin to promote glucose uptake from the blood stream into various cells in the body. In healthy individuals, insulin-mediated cellular signaling lowers/manages blood glucose by (i) secreting appropriate situation-dependent amounts of insulin from the pancreatic $\beta$-cells (ii) enhancing the uptake of glucose in non-hepatic peripheral tissues through translocation of glucose transporters $\{$ ie. Sodiumindependent transporter (GLUT4)\} (iii) promoting hepatic glucose uptake/utilization/storage and suppression of hepatic glucose production, and (iv) inhibiting lipolysis and promoting lipogenesis in adipose tissue. However, in diabetic conditions, particularly T2DM, insulin-mediated cellular signaling is impaired (insulin resistance) resulting in reduced tissue uptake, reduced suppression of hepatic glucose production, increased plasma glucose concentration in the fasting and/or postprandial state; and while still functioning, increased insulin secretion by the pancreas (eg., hyperinsulinemia) [18].

\subsubsection{Enhancing pancreatic $\beta$-cell function: Modification of oxidative stress responses increasing insulin production, reducing apoptosis and promoting $\beta$-cell proliferation}

The inability of pancreatic $\beta$-cells to secrete sufficient amounts of insulin to overcome insulin resistance is one of the main etiological factors in T2DM. Several factors are known to contribute to progressive loss of pancreatic $\beta$-cell function in subjects with diabetes. However, the exact mechanisms involved with insufficient insulin secretion concurrent with peripheral insulin resistance remains to be established. In vitro studies with pancreatic $\beta$-cells suggest that mimicking diabetes (high glucose concentrations), glucose-induced oxidative stress, increased apoptosis and reduced cell proliferation play a significant role in reducing insulin secretion [19]. Several findings using antioxidants imply that oxidative stress is an important factor in pancreatic $\beta$ cell dysfunction in diabetes [20]. Moreover, oral hypoglycemic agents (e.g., sulfonylurea-based drugs that stimulate insulin secretion from pancreatic $\beta$-cells) have been widely used to increase insulin secretion sufficiently to overcome peripheral insulin resistance and normalize blood glucose levels in patients with T2DM [21].

Extracts of the Canadian blueberry $(12.5 \mu \mathrm{g} / \mathrm{mL})$ show increases in 3H-thymidine incorporation in replicating $\beta$ - TC-tet cells by 2.8 -fold (increase in cell proliferation) and may represent another potential anti-diabetic property [22] (Table 3). Administration of Chinese bayberry fruit extracts ( $150 \mu \mathrm{g}$ of cyanidin-3-glucoside/10 g of body weight- twice per day) significantly reduced fasting blood glucose and increased the oral glucose tolerance in streptozotocin-induced diabetic mice model $(P<0.05)$ [23] (Table 2). An in vitro evaluation of Chinese bayberry fruit suggested protective effects against oxidative stress-induced injury in pancreatic $\beta$-cells. Pretreatment of pancreatic $\beta$-cells with bayberry fruit extracts (containing $0.5 \mu \mathrm{mol} / \mathrm{L}$ cyanidin-3-glucoside) prevented cell death, increased cellular viability, and decreased mitochondrial reactive oxygen species production and cell necrosis induced by $\mathrm{H}_{2} \mathrm{O}_{2}$ ( 800 or $1,200 \mu \mathrm{mol} / \mathrm{L}$ ). Furthermore, they observed that bayberry fruit extracts dosedependently up-regulated pancreatic duodenal homeobox 1 gene expression, contributing to increased insulin-like growth factor II gene transcript levels and insulin protein in INS-1 cell [23] (Table 3). Bayberry extracts have been shown to prevent $\mathrm{H}_{2} \mathrm{O}_{2}$ induced cell injury via ERK1/2- and PI3K/Akt-mediated HO-1 upregulation in vitro in pancreatic $\beta$-cells [24]. In a separate study, pretreatment with anthocyanins attenuated autophagic cell death caused by $\mathrm{H}_{2} \mathrm{O}_{2}$ exposure in vitro in pancreatic $\beta$-cells [25] (Table 3).

Rugina et al. [26] showed that chokeberry anthocyanin extract $(1,5$, and $10 \mu \mathrm{M})$ protected mouse pancreatic $\beta$-cells (TC3) against pro-oxidant $\left(\mathrm{H}_{2} \mathrm{O}_{2}\right)$ and high glucose-induced cytotoxicity. They demonstrated that antioxidant enzymes such as superoxide dismutase, catalase, and glutathione peroxidase were increased in the presence of chokeberry anthocyanin extract compared to cells exposed to the pro-oxidants in TC 3 cells. Insulin secretion in TC3 cells was also enhanced by pretreatment with chokeberry anthocyanin extract. Furthermore, chokeberry anthocyanin extract restored insulin secretion and diminished intracellular reactive oxygen species 
level in glucose-induced stress condition in TC3. These results demonstrate that chokeberry anthocyanin extract were biologically active, showing protection of endogenous antioxidant enzymatic systems against pro-oxidants and high glucose in pancreatic $\beta$-cells [26]. Taken together, available in vitro cell culture data with berry extracts suggest favorable effects on impaired pancreatic $\beta$-cells function via reducing oxidative stress, enhancing insulin production, reducing apoptosis and promoting cell proliferation (Table 3, Fig. 1).

\subsubsection{Enhancing peripheral tissue insulin sensitivity: Modification of inflammation/oxidative stress responses in peripheral tissues}

Insulin resistance is a multifactorial and complex metabolic disorder that defies explanation by a single etiological pathway. Among the possible factors, oxidative stress and inflammation play a significant role in impaired insulin signaling. Berry fruits, a rich source of polyphenolic compounds have been consistently shown to reduce oxidative stress and inflammation $[13,27]$.

A study published by our group on the acute postprandial effects of strawberries in a milk-based beverage $(10 \mathrm{~g}$ of freeze-dried strawberry powder; $94.7 \mathrm{mg}$ of total polyphenols) with a high carbohydrate and high fat meal in 24 overweight individuals indicated a modest yet significant reduction in the postprandial insulin response compared to control (placebo) $(P<0.05)$ [28]. The control beverage was matched for sensory attributes, total calories, and macronutrients. Furthermore, the postprandial concentrations of strawberry polyphenols and their metabolites were significantly increased when the strawberry beverage was consumed concurrently with the high carbohydrate and high fat meal, which was not observed after subjects drank the placebo beverage $(P<0.001)$. The strawberry beverage also significantly attenuated the postprandial inflammatory response as measured by interleukin-6 (IL-6) and high-sensitivity C-reactive protein (hsCRP) $(P<0.05)$ induced by the high carbohydrate and high fat meal suggesting a possible association between the reduced insulin response and inflammation [28] (Table 1). It is also interesting to note that in vitro data from our laboratory indicated that oxidative stress induced by $\mathrm{H}_{2} \mathrm{O}_{2}(50 \mu \mathrm{M})$ increased inhibitory serine phosphorylation of insulin receptor substrate-1 (ser-307IRS-1) and decreased the activation of tyrosine residues (p-tyr-IRS-1) (both critical intermediates in the insulin signaling pathway) in human skeletal muscle cells (HSMC). Strawberry extracts prepared in phosphate buffered saline $(0.1-1.0 \mathrm{mg} / \mathrm{mL})$ restored tyrosine phosphorylation in IRS-1 [29]. Another in vitro study performed with human HSMC indicated that elevated glucose $(10 \mathrm{mM})$, free fatty acids (FFA) $(2 \mathrm{mM})$ and the combination of FFA and glucose treatment significantly lowered the p-Akt and p-Insulin Receptor $\beta$ (Tyr1150/1151) protein $(p<0.05)$ compared to control (cell culture media) indicating an impairment in insulin signaling in vitro in HSMCs. Co-treatment of HSMC with strawberry extracts $(0.1-1.0 \mathrm{mg} / \mathrm{mL})$ significantly attenuated the reduced p-Akt protein levels in both the FFA and combination treatments when compared to their corresponding FFA and combination treatments without strawberry $(p<0.05)$. Strawberry extract showed trends in restoring the FFA and or glucose induced decreased phosphorylation of Insulin Receptor $\beta$ (Tyr1150/1151), although the data were not significantly different $(p>0.05)$ [30]. Taken together these in vitro cell culture and human clinical data suggest, but do not confirm that strawberry polyphenolic compounds contribute to improved insulin signaling, suggesting a potential role in reducing insulin resistance (Table 3). Accordingly, we tested the acute effects of strawberry consumption in obese people with insulin resistance [31]. In a dose response study, strawberry intake with a high carbohydrate and high fat meal reduced the insulin requirement for managing postprandial glycemia when the beverage containing $40 \mathrm{~g}$ freeze-dried strawberry powder delivering $368.8 \pm 12.1 \mu \mathrm{mol} / \mathrm{beverage}$ anthocyanins was consumed. This study is the first study to observe the postprandial glycemic control independent of the fiber content in strawberry [31]. Several other studies have also shown beneficial effects of strawberry that may be relevant in providing significant benefits for reducing transition to diabetes or managing existing diabetes $[13,32]$. Collectively this work with strawberries is promising and supports further studies to understand the mechanisms on insulin signaling and protocols for chronic intake.

Blueberry consumption also has shown anti-diabetic activity in human subjects. A double-blinded and placebocontrolled study conducted by Stull et al. [33] showed that daily dietary supplementation of freeze-dried whole blueberry powder (smoothie containing $22.5 \mathrm{~g}$ blueberry powder twice a day) significantly improved insulin 
Table 1

Summary of the research studies involving human subjects showing anti-diabetic effect of Berry Fruits

\begin{tabular}{|c|c|c|c|}
\hline Berry Fruit & Intervention & Effects/Significant Variation & References \\
\hline Strawberry & $\begin{array}{l}\text { RCT, } 2 \text { arm, PP cross over design with } \\
\text { overweight adults. } 0 \text { or } 10 \mathrm{~g} \text { of } \\
\text { freeze-dried strawberry powder, } \\
n=24\end{array}$ & $\begin{array}{l}\text { Strawberry significantly reduced } \\
\text { postprandial insulin response to a } \\
\text { high carbohydrate/high fat meal } \\
(P<0.05), \text { Reduced postprandial } \\
\text { inflammatory response (IL-6 and } \\
\text { hsCRP) }(P<0.05)\end{array}$ & $\begin{array}{l}\text { Edirisinghe et } \\
\text { al. [28] }\end{array}$ \\
\hline Strawberry & $\begin{array}{l}\text { RCT, } 4 \text { arm PP crossover, } \\
\text { dose-response }(0,10,20 \text { and } 40 \mathrm{~g} \\
\text { Freezer dried strawberry), obese } \\
\text { adults with Insulin Resistance, } n=21\end{array}$ & $\begin{array}{l}\text { Strawberry significantly reduced the } \\
\text { insulin requirement for managing } \\
\text { meal-associated postprandial } \\
\text { glycemia with the beverage } \\
\text { containing } 40 \mathrm{~g} \text { freeze-dried } \\
\text { strawberry powder }\end{array}$ & Park et al. [31] \\
\hline Bilberry & $\begin{array}{l}\text { RCT, } 2 \text { arm, chronic feeding ( } 24 \mathrm{wk} \text { ) } \\
\text { design. } 160 \text { mg of anthocyanins } \\
\text { purified from the bilberry } \\
\text { (Vaccinium myrtillus) and } \\
\text { blackcurrant (Ribes nigrum) twice } \\
\text { daily in T2DM patients }(n=58)\end{array}$ & $\begin{array}{l}\text { Significantly lowered fasting plasma } \\
\text { glucose }(P<0.05) \text { and homeostasis } \\
\text { model assessment for insulin } \\
\text { resistance index }(P<0.05) \text {, and } \\
\text { increased serum adiponectin } \\
(P<0.01) \text { and b-hydroxybutyrate } \\
(P=0.01) \text { compared to placebo. }\end{array}$ & Li et al. [54] \\
\hline Blueberry & $\begin{array}{l}\text { RCT, } 2 \text { arm, chronic feeding ( } 6 \mathrm{wk}) \text {. } \\
\text { Obese, nondiabetic, insulin-resistant } \\
\text { participants with freeze-dried whole } \\
\text { blueberry powder ( } 22.5 \mathrm{~g} \text { powder) }\end{array}$ & $\begin{array}{l}\text { Significantly improved insulin } \\
\text { sensitivity }(p<0.05)\end{array}$ & Stull et al. [33] \\
\hline $\begin{array}{l}\text { Lingonberry and } \\
\text { Blackcurrent }\end{array}$ & $\begin{array}{l}\text { RCT, } 4 \text { arm, PP crossover design. } \\
\text { Healthy subject }(n=20) \text { consumed } \\
\text { lingonberries or blackcurrant as } \\
\text { whole berries }(150 \mathrm{~g} \text { served as } \\
\text { purees) or nectars }(300 \mathrm{~mL})\end{array}$ & $\begin{array}{l}\text { Both fruits significantly reduced } \\
\text { sucrose induced postprandial glucose } \\
\text { and insulin concentrations during the } \\
\text { first } 30 \text { min post-intake and a slower } \\
\text { decline during the second hour and a } \\
\text { significantly improved glycemic } \\
\text { profile }(p<0.05) \text {. Prevented the } \\
\text { sucrose-induced late postprandial } \\
\text { hypoglycemic response and the } \\
\text { compensatory free fatty acid } \\
\text { rebound. }\end{array}$ & $\begin{array}{l}\text { Torronen et al. } \\
\text { [40] }\end{array}$ \\
\hline Açai berry & $\begin{array}{l}1 \text { arm study. Healthy overweight men } \\
\text { and women with } 100 \mathrm{~g} \text { açai pulp } \\
\text { twice daily for } 1 \text { month, } n=10\end{array}$ & $\begin{array}{l}\text { Reductions in fasting glucose and } \\
\text { insulin concentrations after } 1 \text { month } \\
\text { of intake compared to baseline } \\
\text { values (both } p<0.02) \text { and } \\
\text { significantly attenuated post-prandial } \\
\text { plasma glucose following the } \\
\text { standardized meal, measured as the } \\
\text { area under the curve }(p=0.047)\end{array}$ & $\begin{array}{l}\text { Udani et al. } \\
\text { [38] }\end{array}$ \\
\hline Chokeberry & $\begin{array}{l}1 \text { arm study. T2DM subjects with } \\
\text { chronic feeding of } 200 \mathrm{~mL} / \text { day for } 3 \\
\text { months, } n=25\end{array}$ & $\begin{array}{l}\text { Significantly reduced fasting glucose, } \\
\text { hemoglobin }(\mathrm{Hb}) \mathrm{A} 1 \mathrm{c} \text {, total } \\
\text { cholesterol and triglycerides } \\
\text { compared to baseline (both } p<0.05 \text { ) }\end{array}$ & $\begin{array}{l}\text { Simeonov } \\
\text { et al. [57] }\end{array}$ \\
\hline Maqui Berries & $\begin{array}{l}\text { RCT with moderate glucose } \\
\text { intolerance subjects, } n=10, \text { post PP } \\
\text { study with a single administration of } \\
200 \mathrm{mg} \text { Delphinol }{ }^{\circledR} \text { with rice intake }\end{array}$ & $\begin{array}{l}\text { Delphinol treatment significantly } \\
\text { inhibits post-prandial glucose } \\
\text { increase at time points } 60 \mathrm{~min} \text { and } \\
90 \mathrm{~min}(P<0.05)\end{array}$ & $\begin{array}{l}\text { Hidalgo et al. } \\
\text { [45] }\end{array}$ \\
\hline
\end{tabular}

Foot note: RCT - Randomized control trial, PP - Post prandial, T2DM - Type 2 diabetic mellitus 
Table 2

Summary of the studies involving animal models showing anti-diabetic effect of Berry Fruits

\begin{tabular}{|c|c|c|c|}
\hline Berry Fruit & Intervention & Effects/Significant Variation & References \\
\hline Bilberry & $\begin{array}{l}\text { Diabetic Mice model with chronic feeding of } \\
\text { Bilberry extract } 27 \mathrm{~g} \mathrm{BBE} \mathrm{(} 10 \mathrm{~g} \\
\text { anthocyanin } / \mathrm{kg} \text { diet) for } 5 \text { weeks }\end{array}$ & $\begin{array}{l}\text { Improved hyperglycemia and insulin } \\
\text { sensitivity by targeting AMPK, Glucose } \\
\text { transporter } 4 \text { (GLUT4), and metabolic } \\
\text { enzymes (PEPCK and G6Pase) }\end{array}$ & Takikawa et al. [50] \\
\hline Blueberry & $\begin{array}{l}\text { Diabetic C57b1/6J mice model with acute } \\
\text { feeding of phenolic-rich extract and an } \\
\text { anthocyanin-enriched fraction from } \\
\text { blueberry formulated with Labrasol } \\
\text { (Gavage- } 500 \mathrm{mg} / \mathrm{kg} \text { body wt) }\end{array}$ & $\begin{array}{l}\text { Lowered elevated blood glucose levels by } 33 \\
\text { and } 51 \% \text {, respectively }(P<0.05)\end{array}$ & Grace et al. [35] \\
\hline Maqui berry & $\begin{array}{l}\text { Diabetic rat model with chronic feeding of } \\
\text { Maqui berry preparation }\left(\text { Delphinol }^{\circledR}\right) \text { for } \\
4 \text { months }\end{array}$ & $\begin{array}{l}\text { Significantly lowered fasting blood glucose } \\
\text { levels in a diabetic rat model after } 4 \\
\text { months feeding and the values } \\
\text { indistinguishable from healthy } \\
\text { non-diabetic rats. Furthermore, }\end{array}$ & Hidalgo et al. [45] \\
\hline Maqui berry & $\begin{array}{l}\text { Healthy C57B1/6J mice with Delphinidin } \\
\text { form Maqui berry }\end{array}$ & $\begin{array}{l}\text { Inhibited the Na+-dependant glucose } \\
\text { transport (SGLT-1) in jejunal mucosa. }\end{array}$ & Hidalgo et al. [45] \\
\hline Chinese bayberry & $\begin{array}{l}\text { Streptozotocin-induced diabetic mice model } \\
\text { with bayberry fruit extracts ( } 150 \mu \mathrm{g} \text { of } \\
\text { cyanidin-3-glucoside/10 g of body weight- } \\
\text { twice per day) }\end{array}$ & $\begin{array}{l}\text { Significantly reduced fasting blood glucose } \\
\text { and increased the oral glucose tolerance } \\
(P<0.05)\end{array}$ & Sun et al. [23] \\
\hline
\end{tabular}

sensitivity over $6 \mathrm{wk}$ in obese, nondiabetic, and insulin-resistant participants $(p<0.05$, Table 1$)$. Authors were unable to demonstrate any possible mechanistic explanation since inflammatory markers investigated were not significantly different compared to the placebo group [33]. However, a cross-sectional study of 1997 females aged 18-76 y, suggested that higher intakes of both anthocyanins and flavones were associated with decreased insulin resistance and hs-CRP [34].

The anti-diabetic activity of blueberry feeding has also been studied in diabetic C57b1/6J mice [35]. A phenolic-rich extract and an anthocyanin-enriched fraction from blueberry (gavaged, $500 \mathrm{mg} / \mathrm{kg}$ body wt) formulated with Labrasol, a pharmaceutically acceptable self-microemulsifying drug delivery system that enhances absorption, lowered elevated blood glucose concentrations by 33 and 51\%, respectively in diabetic C57b1/6J mice. The hypoglycemic effects of these formulae were comparable to that of the known anti-diabetic drug, metformin $(27 \%$ at $300 \mathrm{mg} / \mathrm{kg})$. However, it is interesting to note that effects of the phenolic and anthocyanin fractions were not observed when administered without Labrasol, demonstrating the importance of increasing bioavailability/activity of the administered preparations [35]. Although the mechanism of action was not investigated in this study, authors speculated that observed effects are due to antioxidants properties of the compounds investigated (Table 2).

\subsection{Insulin independent mechanisms}

Circulating blood glucose levels serve as the main regulator of the rate of insulin secretion from the pancreatic $\beta$-cell, which, in turn, regulate circulating blood glucose. The major determinant of how quickly glucose appears in the systemic circulation during the fed state is determined by the rate of gastrointestinal tract digestion and absorption [36]. Furthermore, energy homeostasis at the cellular and whole body level has been proposed as a 
Table 3

Summary of the research studies involving in vitro models showing anti-diabetic effect of Berry Fruits

\begin{tabular}{|c|c|c|c|}
\hline Berry Fruit & Intervention & Effects/Significant Variation & References \\
\hline Strawberry & $\begin{array}{l}\text { In vitro study with human skeletal } \\
\text { muscle cells treated with } \\
\text { strawberry extracts } \\
(0.1-1.0 \mathrm{mg} / \mathrm{mL})\end{array}$ & $\begin{array}{l}\text { Restored impaired tyrosine } \mathrm{p} \text { - IRS-1 } \\
\text { (tyrosine) induced by Oxidative stress } \\
\left(50 \mu \mathrm{M}-\mathrm{H}_{2} \mathrm{O}_{2}\right)(p<0.05)\end{array}$ & Sandhya et al. [29] \\
\hline Strawberry & $\begin{array}{l}\text { In vitro study with human skeletal } \\
\text { muscle cells treated with } \\
\text { strawberry extracts } \\
(0.1-1.0 \mathrm{mg} / \mathrm{mL})\end{array}$ & $\begin{array}{l}\text { Significantly attenuated the reduced insulin } \\
\text { induced p-Akt protein levels in the } \\
\text { presences of high concentration of FFA } \\
\text { and combination of FFA and glucose } \\
\text { solutions }(p<0.05)\end{array}$ & $\begin{array}{l}\text { Kanagath } \\
\text { et al. [30] }\end{array}$ \\
\hline Strawberry & $\begin{array}{l}\text { Caco-2 intestinal cell model on } \\
\text { glucose transport from the } \\
\text { intestinal lumen into cells and also } \\
\text { the GLUT2-facilitated exit on the } \\
\text { basolateral side. }\end{array}$ & $\begin{array}{l}\text { Strawberry polyphenols inhibit glucose } \\
\text { transport from the intestinal lumen into } \\
\text { cells and also the GLUT2-facilitated exit } \\
\text { on the basolateral side. In particular, } \\
\text { pelargonidin-3-O-glucoside in strawberry } \\
\text { (IC } 50=802 \mathrm{mM} \text { ) contributed } 26 \% \text { to the } \\
\text { total inhibition by the strawberry extract. }\end{array}$ & $\begin{array}{l}\text { Manzano and } \\
\text { Williamson. } \\
\text { [43] }\end{array}$ \\
\hline Lingonberry & $\begin{array}{l}\text { In vitro study with } \mathrm{C} 2 \mathrm{C} 12 \text { myoblasts } \\
\text { on glucose uptake in the presence } \\
\text { of Quercetin-rich extract from } \\
\text { lingonberry }\end{array}$ & $\begin{array}{l}\text { Increased insulin-independent glucose } \\
\text { uptake and stimulated AMPK }\end{array}$ & Eid et al. [55] \\
\hline Chokeberry & $\begin{array}{l}\text { In vitro, pancreatic } \beta \text {-cells with } \\
\text { anthocyanin extract }(1,5 \text {, and } \\
10 \mu \mathrm{M}) \text {. Cells challenged with } \\
\mathrm{H}_{2} \mathrm{O}_{2} \text { and high glucose }\end{array}$ & $\begin{array}{l}\text { Protect pancreatic- } \beta \text { cells against } \mathrm{H}_{2} \mathrm{O}_{2} \text { - and } \\
\text { high glucose-induced cytotoxicity. Insulin } \\
\text { secretion in pancreatic- } \beta \text { cells was also } \\
\text { enhanced by pretreatment of chokeberry } \\
\text { anthocyanin extract }\end{array}$ & Rugina et al. [26] \\
\hline $\begin{array}{l}\text { Berry extract from } \\
\text { combination of } \\
\text { blueberry, } \\
\text { bilberry, } \\
\text { cranberry, } \\
\text { elderberry, } \\
\text { raspberry seeds } \\
\text { and strawberry }\end{array}$ & $\begin{array}{l}\text { Acute exposure }(15 \mathrm{~min}) \text { of } \mathrm{Caco}-2 \\
\text { intestinal cell model with } 0.125 \% \text {, } \\
\text { w/v- the anthocyanin content } \\
\text { consists of: cyanidins } 44.5 \% \text {; } \\
\text { delphinidins } 26.1 \% \text {; petunidins } \\
14.4 \% \text {; malvidins } 8.9 \%)\end{array}$ & $\begin{array}{l}\text { Significantly decreased both } \\
\text { sodium-dependent (total uptake) and } \\
\text { sodium-independent (facilitated uptake) } \\
{ }^{3} \mathrm{H}-\mathrm{D} \text {-glucose uptake in human intestinal } \\
\text { Caco- } 2 \text { cells. Chronic treatment }(16 \mathrm{hr}) \text { of } \\
\text { berry indicated that SGLT1 mRNA and } \\
\text { GLUT2 mRNA expression were reduced } \\
\text { significantly }(P<0.05)\end{array}$ & Alzaid et al. [44] \\
\hline $\begin{array}{l}\text { Berry extracts } \\
\text { from } \\
\text { strawberries, } \\
\text { black currants, } \\
\text { arctic brambles, } \\
\text { cloudberries, } \\
\text { blueberries and } \\
\text { rowanberries }\end{array}$ & In vitro enzymatic study & $\begin{array}{l}\text { Modulated starch digestion as berry extracts } \\
\text { inhibit both } \alpha \text {-amylase activity and } \\
\alpha \text {-glucosidase activity in vitro at low levels }\end{array}$ & Boath et al. [46] \\
\hline
\end{tabular}


Table 3

(Continued)

\begin{tabular}{|c|c|c|c|}
\hline Berry Fruit & Intervention & Effects/Significant Variation & References \\
\hline Raspberry & In vitro enzymatic study & $\begin{array}{l}\text { Ellagitannins in raspberry was the main } \\
\text { active components for amylase } \\
\text { inhibition }\end{array}$ & $\begin{array}{l}\text { McDougall et al. } \\
\text { [48] }\end{array}$ \\
\hline Blackberry & In vitro enzymatic study & $\begin{array}{l}\text { Inhibitory activity on } \alpha \text {-amylase and } \\
\alpha \text {-glucosidase }\end{array}$ & $\begin{array}{l}\text { Šaponjac et al. } \\
\text { [49] }\end{array}$ \\
\hline $\begin{array}{l}\text { Canadian } \\
\text { Blueberry }\end{array}$ & $\begin{array}{l}\text { In vitro } \beta \text {-TC-tet model (pancreatic } \\
\quad \beta \text {-cells) }\end{array}$ & $\begin{array}{l}\text { 3H-thymidine incorporation in } \\
\text { replicating } \beta \text { - TC-tet cells by } 2.8 \text {-fold } \\
\text { (increase in cell proliferation) }\end{array}$ & $\begin{array}{l}\text { Martineau et al. } \\
\text { [22] }\end{array}$ \\
\hline Chinese bayberry & $\begin{array}{l}\text { In vitro pancreatic } \beta \text {-cells treated } \\
\text { with fruit extracts (containing } \\
0.5 \mu \mathrm{mol} / \mathrm{L} \text { cyanidin-3-glucoside) } \\
\text { and } \mathrm{H}_{2} \mathrm{O}_{2}(800 \text { or } 1,200 \mu \mathrm{mol} / \mathrm{L})\end{array}$ & $\begin{array}{l}\text { Pretreatment of pancreatic } \beta \text { cells } \\
\text { prevented cell death, increased cellular } \\
\text { viability, and decreased mitochondrial } \\
\text { reactive oxygen species production } \\
\text { and cell necrosis induced by } \mathrm{H}_{2} \mathrm{O}_{2}\end{array}$ & Sun et al. [23] \\
\hline Chinese bayberry & $\begin{array}{l}\text { In vitro Pancreatic } \beta \text {-cells treated } \\
\text { with bayberry fruit extracts and } \\
\mathrm{H}_{2} \mathrm{O}_{2}\end{array}$ & $\begin{array}{l}\text { Prevents } \mathrm{H}_{2} \mathrm{O}_{2} \text { induced cell injury via } \\
\text { ERK1/2- and } \mathrm{PI} 3 \mathrm{~K} / \text { Akt-mediated } \\
\mathrm{HO}-1 \text { upregulation in vitro in } \\
\text { pancreatic } \beta \text {-cells }\end{array}$ & Zhang et al. [24] \\
\hline Chinese bayberry & $\begin{array}{l}\text { In vitro Pancreatic } \beta \text {-cells treated } \\
\text { with bayberry fruit extracts and } \\
\mathrm{H}_{2} \mathrm{O}_{2}\end{array}$ & $\begin{array}{l}\text { Attenuates autophagic cell death caused } \\
\text { by } \mathrm{H}_{2} \mathrm{O}_{2} \text { exposure in vitro in } \\
\text { pancreatic } \beta \text { cells }\end{array}$ & Zhang et al. [25] \\
\hline
\end{tabular}

potential mechanism for glucose-lowering effect results from decreased hepatic glucose production and increased glucose utilization [37].

\subsubsection{Inhibition of digestive enzymes involved in carbohydrate breakdown and glucose absorption in gastrointestinal track}

Several studies have suggested that anti-diabetic effects derived from polyphenols rich berry fruits may be partly through the effects carried out within the gastrointestinal tract. In particular, in vitro and in vivo animal data indicated that polyphenols may modulate nutrient availability such as glucose through the inhibition of digestive enzymes involved in carbohydrate breakdown and absorption, which could influence blood glucose control. However, in vivo effects of polyphenolic compounds derived from berries are based upon glycemia or glucose tolerance data rather than on the direct effect of polyphenolic compounds upon the intestinal digestion of carbohydrates and absorption of glucose [38, 39].

A postprandial study published by Torronen et al. [40] on healthy women $(n=20)$ indicated that lingonberries, as either whole berries $(150 \mathrm{~g}$ served as purees) or nectars $(300 \mathrm{~mL})$, reduced sucrose (each with $35 \mathrm{~g}$ added sucrose) induced postprandial glucose and insulin concentrations during the first $30 \mathrm{~min}$ post-intake. Additionally, a slower decline during the second hour was observed with whole berries or nectars as well as a significantly improved overall glycemic profile $(p<0.05)$. Furthermore, they observed, berries and nectars prevented the sucrose-induced late postprandial hypoglycemic response and the compensatory free fatty acid rebound. These data suggested a delayed digestion of sucrose and consequent slower absorption of glucose (Table 1).

Glucose is actively taken up into the enterocytes from the intestinal lumen by the high-affinity, sodiumdependent and phloridzin-sensitive Sodium/glucose co-transporter 1 (SGLT1) located in the brush border of the intestine followed by passively released from the enterocytes into the portal circulation via the glucose 
transporter 2 (GLUT2) present in the basolateral membrane. Most of the in vitro studies are conducted with individual polyphenolic compounds that are commonly available in berry fruits [41]. Catechins and quercetin3-O-glucoside were found to inhibit the transport activity of SGLT1 [42]. A study by Manzano and Williamson, [43] using Caco-2 intestinal cell monolayers showed that strawberry polyphenols, phenolic acids and tannins inhibit glucose transport from the intestinal lumen into cells and also the GLUT2-facilitated exit on the basolateral side. In particular, pelargonidin-3-O-glucoside in strawberry $\left(\mathrm{IC}_{50}=802 \mathrm{mM}\right)$ contributed $26 \%$ to the total inhibition by the strawberry extract. An in vitro study by Alzaid et al. [44] showed that acute exposure (15 $\mathrm{min})$ to berry extract (derived from blueberry, bilberry, cranberry, elderberry, raspberry seeds and strawberry$0.125 \%$, w/v- the anthocyanin content consists of: cyanidins $44.5 \%$; delphinidins $26.1 \%$; petunidins $14.4 \%$; malvidins $8.9 \%$ ) significantly decreased both sodium-dependent (total uptake) and sodium-independent (facilitated uptake) ${ }^{3} \mathrm{H}$-D-glucose uptake in human intestinal Caco- 2 cells. Chronic treatment $(16 \mathrm{hrs})$ of berry extract with Caco-2 cells indicated that SGLT1 mRNA and GLUT2 mRNA expression were reduced significantly $(P<0.05$, Table 3).

Maqui berry extract (Delphinol ${ }^{\circledR}$ ) containing $\geq 35 \% \mathrm{w} / \mathrm{w}$ total anthocyanins and $\geq 25 \% \mathrm{w} / \mathrm{w}$ total delphinidins has shown to significantly reduce postprandial glucose and insulin concentrations compared to placebo in 10 moderately glucose tolerance subjects $(P<0.05)$ [45] (Table 1$)$. Furthermore, they observed significantly lower fasting blood glucose concentrations in a diabetic rat model after feeding Delphinol ${ }^{\circledR}$ over a period of four months and values were indistinguishable from healthy non-diabetic rats. They also demonstrated that delphinidin inhibited the Na+-dependent glucose transport (SGLT-1) in jejunal mucosa of healthy C57B1/6J mice, and proposed glucose transport inhibition as primary mechanism of action of delphinidin, the main polyphenol in present in Delphinol ${ }^{\circledR}[45]$ (Table 2).

A study by Boath et al. [46] indicated that polyphenols from berries (extracted from strawberries, black currants, arctic brambles, cloudberries, blueberries and rowanberries) also have the potential to modulate starch digestion as they inhibit both $\alpha$-amylase activity and $\alpha$-glucosidase activity in vitro at low levels (Table 3 ). Furthermore, the same group reported that the most effective were from raspberry and rowanberry $\left(\mathrm{IC}_{50}\right.$ values of 21.0 and $4.5 \mu \mathrm{g} / \mathrm{mL}$, respectively) [46, 47]. Extracts derived from yellow and red raspberries were shown to have similar inhibitory effects on $\alpha$-amylase. Yellow raspberry extracts are devoid of anthocyanins, and therefore suggested that anthocyanins are not crucial for amylase inhibition [47]. A study by McDougall et al. [48] strongly suggested that ellagitannins in raspberry were the main active components for amylase inhibition. An extract of blackberry also showed $\alpha$-amylase inhibitory activity and $\alpha$-glucosidase inhibitory activity in vitro [49]. These data indicate a potential for controlling starch digestion in the gastrointestinal tract by enzyme inhibition. However, further work is required to confirm an inhibitory effect of berry components on digestive enzymes in vivo beneficially impacting glycemic responses (Table 3 ).

Collectively, the available literature suggest that berry fruits rich in polyphenols might provide a mechanism for regulating the rate of intestinal glucose digestion and absorption and thereby providing another mechanism for managing diabetes, and in the long term might offer some protection against development of T2DM.

\subsubsection{Modification of energy metabolism/energy status}

Polyphenolic compounds also have been shown to increase glucose uptake through energy homeostasis at both cellular and whole-body levels via a mechanism related to AMP-activated protein kinase (AMPK) [9].

Takikawa et al. [50] investigated the effects of bilberry extract in mice with T2DM by providing them a diet containing $27 \mathrm{~g}$ bilberry extracts $(10 \mathrm{~g}$ anthocyanin $/ \mathrm{kg}$ diet) for a period of 5 weeks (Table 2). Data indicated that BBE improved hyperglycemia and insulin sensitivity in mice with T2DM by targeting AMPK, GLUT4, and metabolic enzymes. Bilberry extract increased total AMPK $\alpha$ and phosphorylation of AMPK $\alpha$ (Thr 172) and subsequently increased GLUT4 in white adipose tissue and skeletal muscle of diabetic mice [50]. Activation of AMPK is associated with increased expression of GLUT4 independent of insulin supporting the ability of bilberry extract to work via an insulin-independent mechanism [51]. Bilberry extract also has been shown to downregulate the expression of gluconeogenic enzymes such as PEPCK and Glucose 6-phosphatase and suppress glucose flux 
into the systemic circulation in this study [50]. Furthermore, Takikawa et al. [50] observed that diabetic mice treated with bilberry extract have reduced levels of Retinol-Binding Protein 4 (RBP4) in mesenteric fat. RBP4, an adipocytokine, has been associated with obesity and insulin resistance [52], and is proposed as a potential treatment target for T2DM. These data indicate that anthocyanins derived from berry fruits may favorably regulate glucose homeostasis by modifying lipid metabolism. In support of these data, Guo et al. [53] demonstrated that cyanidin-3-O-glucoside, one of the major anthocyanins present in berry fruits regulates hepatic lipid homeostasis via an AMPK-dependent signaling pathway in vitro in human HepG2 hepatocytes (Table 3). Supplementation of anthocyanins (160 mg of anthocyanins twice daily) purified from the bilberry (Vaccinium myrtillus) and blackcurrant (Ribes nigrum) in people with T2DM offers further support for anti-diabetic activity or disease managing activity of dietary anthocyanins (Table 1). Li et al. [54] reported significantly lower fasting plasma glucose $(P<0.05)$ and homeostasis model assessment for insulin resistance index $(P<0.05)$, and elevated serum adiponectin $(P<0.01)$ and $\beta$-hydroxybutyrate $(P=0.01)$ compared to placebo after the 24 -wk intervention in T2DM patients $(n=58)$. Furthermore, it was observed that anthocyanin supplementation had significant effects on lipid metabolism as measured by significantly decreased serum LDL cholesterol, triglycerides, apolipoprotein (apo) B-48, apo C-III and increased HDL cholesterol $(P<0.05)$ compared with placebo. In addition, patients in the anthocyanin group showed higher total radical-trapping antioxidant parameter and ferric ion reducing antioxidant power values compared to the placebo group (both $P<0.05$ ). Serum concentrations of 8-iso-prostaglandin F2a, 13-hydroxyoctadecadienoic acid, and carbonylated proteins in the anthocyanin group was also significantly less than the placebo group $(P<0.01, p<0.01$ and $P=0.022$, respectively) [54].

An investigation conducted by Eid et al. [55] on the effects of quercetin-rich extract from the lingonberry (Vaccinium vitis idaea) on glucose uptake in vitro in $\mathrm{C} 2 \mathrm{C} 12$ myoblasts indicated that the extract stimulated the AMPK pathway in muscle cells and moderately inhibited adenosine diphosphate (ADP)-stimulated oxygen consumption in isolated mitochondria (Table 3). These actions are similar to the cellular and molecular mechanisms of Metformin. Further, quercetin-3-O-glucoside and quercetin-3-O-alactoside and quercetin aglycone isolated from berry extract showed enhanced insulin-independent glucose uptake and stimulated AMPK in muscle cells. ATP synthase in isolated mitochondria was inhibited only by quercetin aglycone suggesting that removal of the carbohydrate moiety is required for its bioactivity. This in vitro study suggested that quercetin and/or its derivatives are the major bioactive components of lingonberry that are responsible for the activation of AMPK and subsequent stimulation of glucose uptake in muscle cells. One of the drawbacks to this in vitro study is that the dosage $(50 \mu \mathrm{M})$ of quercetin and/or its derivatives used in this study may be too high to achieve physiologically [55].

A pilot study with an Açai berry (Euterpe oleracea Mart.- $100 \mathrm{~g}$ açai pulp twice daily) in healthy overweight men and women $\left(B M I \geq 25 \mathrm{~kg} / \mathrm{m}^{2}\right.$ and $\left.\leq 30 \mathrm{~kg} / \mathrm{m}^{2}\right)$ indicated reductions in fasting glucose and insulin concentrations after 1 month of intake compared to baseline values (both $p<0.02$ ) [38] (Table 1). There was also a reduction in total cholesterol $(p=0.03)$ as well as borderline significant reductions in LDL-cholesterol and the ratio of total cholesterol to HDL-cholesterol (both $p=0.051$ ). Furthermore, treatment with the açai berry preparation significantly attenuated the post-prandial increase in plasma glucose following the standardized meal, measured as the area under the curve $(p=0.047)$. There was no effect on hs-CRP or plasma Nitric oxide metabolites [38 ]. However, in a separate human study published by Mertens-Talcott et al. [56] indicated that plasma antioxidant capacity (measured using the ORAC assay) was increased up to 3 fold with a single dose of $7 \mathrm{~mL}$ açaí pulp/kg body weight compared to the control beverage $(p<0.01)$, with a $\mathrm{T}_{\max }$ of $3 \mathrm{~h}$. These data suggest that Açai berry supplementation exerts beneficial metabolic effects in subjects with T2DM by reducing insulin resistance via a mechanism related to improving dyslipidemia and enhancing antioxidant capacity.

Choke berry (Aronia melanocarpa) juice given to subjects with T2DM (200 mL/day for 3 months) significantly reduced fasting glucose levels, hemoglobin $(\mathrm{Hb}) \mathrm{A} 1 \mathrm{c}$ levels, total cholesterol and triglycerides compared to baseline (both $p<0.05)$ [57] (Table 1). However, in another choke berry intervention study $(3 \times 100 \mathrm{mg} /$ day for 2 months) in subjects with metabolic syndrome $(n=25)$, beneficial effects on oxidative stress markers and lipids were observed $(p<0.05)$, but no effect on fasting plasma glucose levels was observed $(P<0.05)$ [58]. 


\section{Summary and future research}

Increasing fruit consumption has been consistently shown to have favorable effects on the prevention and management of many chronic diseases, including T2DM [11]. Among the fruits that have significant health benefits, berry fruits have attracted attention due to their unique and high polyphenolic content. Several epidemiological studies have suggested an inverse relationship between berry fruits and dietary anthocyanin intake and T2DM [10-12]. The anti-diabetic effect of berry phenolic compounds has been demonstrated in human, animal and in vitro cell culture models as discussed in this review (Tables 1-3). In vivo and In vitro data suggested that berry fruits exert their anti-diabetic effects by targeting various cells and cellular signaling pathways involved in glucose homeostasis such as cells in the pancreas, liver, skeletal muscle, and adipose tissues. The observed effects resemble functions/mode of actions to some clinically used anti-diabetic drugs. The anti-diabetic activity of the berry polyphenolics may be due to their antioxidant, anti-inflammatory, carbohydrate digesting enzyme inhibition and absorption in the gastrointestinal tract, cellular receptor agonist or antagonist activity or through novel mechanisms that have not yet been elucidated. However, available literature indicates that observed antidiabetic effects are due to multiple mechanisms involved in glucose homeostasis pathways (Fig. 1, Tables 1-3). It is also encouraging that the berry polyphenolic concentrations used in most of the in vitro reports are physiologically relevant. However, in vivo tissues typically see an array of compounds after berry consumption. Some berry polyphenolic structures can be absorbed intact (i.e. certain anthocyanins), however, most are conjugated, degraded or metabolized to other compounds prior to circulation [17]. The studies on the anti-diabetic effects of metabolites of berry polyphenolic compounds are scarce and are an area that needs future attention. Furthermore, the bioavailability and pharmacokinetic profiles of the parent compounds and/ or their metabolites are important aspects for their respective anti-diabetic activity. Effects in different food systems/matrix are not fully known and are important components to berry fruit bioactivity since berries are consumed not only as a food alone but in combination with other foods/ingredients. The active compounds/sites in berry polyphenolic compounds need to be identified precisely to understand the chemical interactions in food systems, the digestive system and in systemic circulation. Finally well designed human trials with emphasis on mechanism of action are required to further understand the potential actions of berry polyphenolic compounds to prevent and/or manage T2DM.

\section{References}

[1] 2014 National Diabetes Statistics Report, CDC, http://www.cdc.gov/diabetes/data/statistics/2014StatisticsReport.html

[2] Diabetes Fact sheet, Updated March 2016, http://www.who.int/mediacentre/factsheets/fs312/en/

[3] UnitedHealth Center for Health Reform and Modernization. The united states of diabetes: Challenges and opportunities in the decade ahead. 2010.

[4] Fonseca VA, Kirkman MS, Darsow T, Ratner RE. The American Diabetes Association diabetes research perspective. Diabetes. 2012;61(6):1338-45.

[5] Grundy SM, Benjamin IJ, Burke GL, Chait A, Eckel RH, Howard BV, et al. Diabetes and cardiovascular disease: A statement for healthcare professionals from the American Heart Association. Circulation. 1999;100(10):1134-46.

[6] Asif M. The prevention and control the type-2 diabetes by changing lifestyle and dietary pattern. J Educ Health Promot. $2014 ; 3: 1$.

[7] USDA. Dietary Guidelines for Americans 2015-2020. 2015.

[8] Seeram NP. Emerging research supporting the positive effects of berries on human health and disease prevention. J Agric Food Chem. 2012;60(23):5685-6.

[9] Babu PV, Liu D, Gilbert ER. Recent advances in understanding the anti-diabetic actions of dietary flavonoids. J Nutr Biochem. 2013;24(11):1777-89.

[10] Wedick NM, Pan A, Cassidy A, Rimm EB, Sampson L, Rosner B, et al. Dietary flavonoid intakes and risk of type 2 diabetes in US men and women. Am J Clin Nutr. 2012;95(4):925-33.

[11] Muraki I, Imamura F, Manson JE, Hu FB, Willett WC, van Dam RM, et al. Fruit consumption and risk of type 2 diabetes: Results from three prospective longitudinal cohort studies. BMJ. 2013;347:f5001. 
[12] Mursu J, Virtanen JK, Tuomainen TP, Nurmi T, Voutilainen S. Intake of fruit, berries, and vegetables and risk of type 2 diabetes in Finnish men: The Kuopio Ischaemic Heart Disease Risk Factor Study. Am J Clin Nutr. 2014;99(2):328-33.

[13] Joseph SV, Edirisinghe I, Burton-Freeman BM. Fruit polyphenols: A review of anti-inflammatory effects in humans. Crit Rev Food Sci Nutr. 2015:0. PMID: 25616409.

[14] Scalzo J, Politi A, Pellegrini N, Mezzetti B, Battino M. Plant genotype affects total antioxidant capacity and phenolic contents in fruit. Nutrition. 2005;21(2):207-13.

[15] Tulipani S, Mezzetti B, Capocasa F, Bompadre S, Beekwilder J, de Vos CH, Capanoglu E, Bovy A, Battino M. Antioxidants, phenolic compounds, and nutritional quality of different strawberry genotypes. J Agric Food Chem. 56(3):696-704

[16] Hancock R, Stewart D. Enhancing the nutritional quality of fruit juices: Advanced technologies for juice extraction and pasteurization. Bagchi D LF, Ghosh DK, editor: CRC Press; 2010.

[17] Lila MA, Burton-Freeman B, Grace M, Kalt W. Unraveling anthocyanin bioavailability for human health. Annu Rev Food Sci Technol. 2016;7:375-93.

[18] Laville M, Nazare JA. Diabetes, insulin resistance and sugars. Obes Rev. 2009;10(Suppl 1):24-33.

[19] Cernea S, Dobreanu M. Diabetes and beta cell function: From mechanisms to evaluation and clinical implications. Biochem Med (Zagreb). 2013;23(3):266-80.

[20] Lee E, Ryu GR, Ko SH, Ahn YB, Yoon KH, Ha H, et al. Antioxidant treatment may protect pancreatic beta cells through the attenuation of islet fibrosis in an animal model of type 2 diabetes. Biochem Biophys Res Commun. 2011;414(2):397-402.

[21] Cersosimo E, Solis-Herrera C, Trautmann ME, Malloy J, Triplitt CL. Assessment of pancreatic $\beta$-cell function: Review of methods and clinical applications. Curr Diabetes Rev. 2014;10(1):2-42.

[22] Martineau LC, Couture A, Spoor D, Benhaddou-Andaloussi A, Harris C, Meddah B, et al. Anti-diabetic properties of the Canadian lowbush blueberry Vaccinium angustifolium Ait. Phytomedicine. 2006;13(9-10):612-23.

[23] Sun CD, Zhang B, Zhang JK, Xu CJ, Wu YL, Li X, et al. Cyanidin-3-glucoside-rich extract from Chinese bayberry fruit protects pancreatic $\beta$ cells and ameliorates hyperglycemia in streptozotocin-induced diabetic mice. J Med Food. 2012;15(3):288-98.

[24] Zhang B, Kang M, Xie Q, Xu B, Sun C, Chen K, et al. Anthocyanins from Chinese bayberry extract protect $\beta$ cells from oxidative stress-mediated injury via HO-1 upregulation. J Agric Food Chem. 2011;59(2):537-45.

[25] Zhang B, Buya M, Qin W, Sun C, Cai H, Xie Q, et al. Anthocyanins from Chinese bayberry extract activate transcription factor Nrf2 in $\beta$ cells and negatively regulate oxidative stress-induced autophagy. J Agric Food Chem. 2013;61(37):8765-72.

[26] Rugină D, Diaconeasa Z, Coman C, Bunea A, Socaciu C, Pintea A. Chokeberry anthocyanin extract as pancreatic $\beta$-cell protectors in two models of induced oxidative stress. Oxid Med Cell Longev. 2015;2015:429075.

[27] Basu A, Rhone M, Lyons TJ. Berries: Emerging impact on cardiovascular health. Nutr Rev. 2010;68(3):168-77.

[28] Edirisinghe I, Banaszewski K, Cappozzo J, Sandhya K, Ellis CL, Tadapaneni R, et al. Strawberry anthocyanin and its association with postprandial inflammation and insulin. Br J Nutr. 201;110:913-22.

[29] Sandhya K, Tadapaneni R, Banaszewski K, Cappozzo J, Edirisinghe I, Burton-Freeman B. Strawberry extract attenuates oxidative stress-induced impaired insulin signaling in vitro in Human Skeletal Muscle Cells. The FASEB Journal. 2010;24:541.13.

[30] Kanagath A, Chan C, Sandhya K, Banaszewski K, Cappozzo J, Edirisinghe I, Burton-Freeman B. Strawberry extract attenuates glucose and free fatty acid-mediated impaired insulin signaling in vitro in skeletal muscle cells. The FASEB Journal. 2012;26:821.15.

[31] Park E, Edirisinghe I, Wei H, Vijayakumar L.P, Banaszewski K, Cappozzo JC, Burton-Freeman B. A Dose-Response Evaluation of Freeze-Dried Strawberries Independent of Fiber Content on Metabolic Indices in abdominally Obese Individuals with InsulinResistance in a Randomized, Single-blinded, Diet-controlled Crossover Trial. Journal of Molecular Nutrition and Food Research. 2016. DOI: $10.1002 / \mathrm{mnfr} .201500845$

[32] Giampieri F, Alvarez-Suarez JM, Battino M. Strawberry and human health: Effects beyond antioxidant activity. J Agric Food Chem. 2014;62(18):3867-76.

[33] Stull AJ, Cash KC, Johnson WD, Champagne CM, Cefalu WT. Bioactives in blueberries improve insulin sensitivity in obese, insulin-resistant men and women. J Nutr. 140(10) 1764-8.

[34] Jennings A, Welch AA, Spector T, Macgregor A, Cassidy A. Intakes of anthocyanins and flavones are associated with biomarkers of insulin resistance and inflammation in women. J Nutr. 2014;144(2):202-8.

[35] Grace MH, Ribnicky DM, Kuhn P, Poulev A, Logendra S, Yousef GG, et al. Hypoglycemic activity of a novel anthocyanin-rich formulation from lowbush blueberry, Vaccinium angustifolium Aiton. Phytomedicine. 2009;16(5):406-15.

[36] Aronoff SL, Berkowitz K, Shreiner B, Want L. Glucose metabolism and regulation: Beyond insulin and glucagon. Diabetes Spectrum. 2004;17(3):183-90.

[37] Zhou G, Myers R, Li Y, et al. Role of AMP-activated protein kinase in mechanism of metformin action. JCI. 2001;108(8):1167-1174.

[38] Udani JK, Singh BB, Singh VJ, Barrett ML. Effects of Açai (Euterpe oleracea Mart.) berry preparation on metabolic parameters in a healthy overweight population: A pilot study. Nutrition Journal. 2011;10(1):1-7. 
[39] Attele AS, Zhou YP, Xie JT, Wu JA, Zhang L, Dey L, et al. Anti-diabetic effects of Panax ginseng berry extract and the identification of an effective component. Diabetes. 2002;51(6):1851-8.

[40] Törrönen R, Kolehmainen M, Sarkkinen E, Mykkänen H, Niskanen L. Postprandial glucose, insulin, and free fatty acid responses to sucrose consumed with blackcurrants and lingonberries in healthy women. Am J Clin Nutr. 2012;96(3):527-33.

[41] Kwon O, Eck P, Chen S, Corpe CP, Lee JH, Kruhlak M, et al. Inhibition of the intestinal glucose transporter GLUT2 by flavonoids. FASEB J. 2007;21(2):366-77.

[42] Martel F, Monteiro R, Calhau C. Effect of polyphenols on the intestinal and placental transport of some bioactive compounds. Nutr Res Rev. 2010;23(1):47-64.

[43] Manzano S, Williamson G. Polyphenols and phenolic acids from strawberry and apple decrease glucose uptake and transport by human intestinal Caco-2 cells. Mol Nutr Food Res. 2010;54(12):1773-80.

[44] Alzaid F, Cheung HM, Preedy VR, Sharp PA. Regulation of glucose transporter expression in human intestinal Caco-2 cells following exposure to an anthocyanin-rich berry extract. PLoS One. 2013;8(11):e78932.

[45] Hidalgo J, Flores C, Hidalgo MA, Perez M, Yañez A, Quiñones L, et al. Delphinol ${ }^{\circledR}$ standardized maqui berry extract reduces postprandial blood glucose increase in individuals with impaired glucose regulation by novel mechanism of sodium glucose cotransporter inhibition. Panminerva Med. 2014;56(2 Suppl 3):1-7.

[46] Boath AS, Grussu D, Stewart D, McDougall GJ. Berry polyphenols inhibit digestive enzymes: A source of potential health benefits? Food Digestion. 2012;3(1-3):1-7.

[47] Grussu D, Stewart D, McDougall GJ. Berry polyphenols inhibit $\alpha$-amylase in vitro: Identifying active components in rowanberry and raspberry. J Agric Food Chem. 2011;59(6):2324-31.

[48] McDougall GJ, Shpiro F, Dobson P, Smith P, Blake A, Stewart D. Different polyphenolic components of soft fruits inhibit alpha-amylase and alpha-glucosidase. J Agric Food Chem. 2005;53(7):2760-6.

[49] Šaponjac VT, Gironés-Vilaplana A, Djilas S, Mena P, Cetković G, Moreno DA, et al. Anthocyanin profiles and biological properties of caneberry (Rubus spp.) press residues. J Sci Food Agric. 2014;94(12):2393-400.

[50] Takikawa M, Inoue S, Horio F, Tsuda T. Dietary anthocyanin-rich bilberry extract ameliorates hyperglycemia and insulin sensitivity via activation of AMP-activated protein kinase in diabetic mice. J Nutr. 2010;140(3):527-33.

[51] Hardie DG. Role of AMP-activated protein kinase in the metabolic syndrome and in heart disease. FEBS Lett. 2008;582(1):81-9.

[52] Yang Q, Graham TE, Mody N, Preitner F, Peroni OD, Zabolotny JM, et al. Serum retinol binding protein 4 contributes to insulin resistance in obesity and type 2 diabetes. Nature. 2005;436(7049):356-62.

[53] Guo H, Liu G, Zhong R, Wang Y, Wang D, Xia M. Cyanidin-3-O- $\beta$-glucoside regulates fatty acid metabolism via an AMP-activated protein kinase-dependent signaling pathway in human HepG2 cells. Lipids Health Dis. 2012;11:10.

[54] Li D, Zhang Y, Liu Y, Sun R, Xia M. Purified anthocyanin supplementation reduces dyslipidemia, enhances antioxidant capacity, and prevents insulin resistance in diabetic patients. J Nutr. 2015;145(4):742-8.

[55] Eid HM, Martineau LC, Saleem A, Muhammad A, Vallerand D, Benhaddou-Andaloussi A, et al. Stimulation of AMP-activated protein kinase and enhancement of basal glucose uptake in muscle cells by quercetin and quercetin glycosides, active principles of the anti-diabetic medicinal plant Vaccinium vitis-idaea. Mol Nutr Food Res. 2010;54(7):991-1003.

[56] Mertens-Talcott SU, Rios J, Jilma-Stohlawetz P, Pacheco-Palencia LA, Meibohm B, Talcott ST, et al. Pharmacokinetics of anthocyanins and antioxidant effects after the consumption of anthocyanin-rich acai juice and pulp (Euterpe oleracea Mart.) in human healthy volunteers. J Agric Food Chem. 2008;56(17):7796-802.

[57] Simeonov SB, Botushanov NP, Karahanian EB, Pavlova MB, Husianitis HK, Troev DM. Effects of Aronia melanocarpa juice as part of the dietary regimen in patients with diabetes mellitus. Folia Med (Plovdiv). 2002;44(3):20-3.

[58] Broncel M, Kozirog M, Duchnowicz P, Koter-Michalak M, Sikora J, Chojnowska-Jezierska J. Aronia melanocarpa extract reduces blood pressure, serum endothelin, lipid, and oxidative stress marker levels in patients with metabolic syndrome. Med Sci Monit. 2010;16(1):CR28-34. 